\title{
ANALISIS PENGARUH INFLASI, BI RATE, NILAI TUKAR KURS, INDEKS HANG SENG DAN INDEKS DOW JONES TERHADAP RETURN SAHAM (STUDI EMPIRIS PT. SEMEN INDONESIA PERIODE 2009-2016)
}

\author{
Erga Armela Febrianti' ${ }^{1)}$, Abd. Rohman Taufiq ${ }^{2)}$ \\ Program Studi Akuntansi, Universitas PGRI Madiun \\ ergaarmela@gmail.com \\ supermen.rohman@gmail.com
}

ABSTRACT

This study aims to provide empirical evidence of partial or simultaneous influence between Inflation, BI Rate, Exchange Rate, Hang Seng Index and Dow Jones Index on Stock Return (Empirical Study of PT. Semen Indonesia Period 2009-2016). The type of research used in this study is quantitative research. Population in this research is PT. Semen Indonesia The Period 2009-2016). The number of samples is 32. Data analysis used is descriptive statistics, classical assumption test, multiple linear regression, and hypothesis test using SPSS version 16.0. The simultaneous test results (F test) of all variables Inflation, BI Rate, Exchange Rate, Hang Seng Index and Dow Jones Index simultaneously affect the Stock Return of Share of 4.781.

Keywords: Inflation, BI Rate, Exchange Rate, Hang Seng Index, Dow Jones Index, Stock Return.

\begin{abstract}
ABSTRAK
Penelitian ini bertujuan untuk memberikan bukti empiris tentang pengaruh secara parsial maupun secara simultan antara Inflasi, BI Rate, Nilai Tukar Kurs, Indeks Hang Seng Dan Indeks Dow Jones Terhadap Return Saham (Studi Empiris PT. Semen Indonesia Periode 2009-2016). Jenis penelitian yang digunakan dalam penelitian ini adalah penelitian kuantitatif. Populasi dalam penelitian ini adalah PT. Semen Indonesia Periode 20092016). Jumlah sampel sebesar 32. Analisis data yang digunakan adalah statistik deskriptif, uji asumsi klasik, regresi linier berganda, dan uji hipotesis dengan menggunakan program SPSS versi 16.0. Hasil uji simultan (uji F) semua variabel Inflasi, BI Rate, Nilai Tukar, Indeks Hang Seng dan Indeks Dow Jones secara simultan berpengaruh terhadap Return Saham sebesar 4,781.

Kata Kunci: Inflasi, BI Rate, Nilai Tukar Kurs, Indeks Hang Seng, Indeks Dow Jones, Return Saham.
\end{abstract}

\section{PENDAHULUAN}

Pasar modal memiliki peran penting bagi perekonomian suatu negara karena pasar modal menjalankan dua fungsi, yaitu pertama sebagai sarana bagi pendanaan usaha atau sebagai sarana bagi perusahaan untuk mendapatkan dana dari masyarakat pemodal atau investor. Dana yang diperoleh dari pasar modal dapat digunakan untuk pengembangan usaha, ekspansi, penambahan modal kerja dan lainlain. Kedua, pasar modal menjadi sarana bagi masyarakat untuk berinvestasi pada instrumen keuangan seperti saham, obligasi, reksa dana, dan lain-lain. Dengan demikian, masyarakat dapat menempatkan dana yang dimilikinya sesuai dengan karakteristik keuntungan dan risiko masing-masing instrumen keuangan. Harga saham di bursa tidak selamanya tetap, adakalanya 
meningkat dan bisa pula menurun, tergantung pada kekuatan permintaan dan penawaran. Di pasar modal, terjadinya fluktuasi harga saham tersebut menjadikan bursa efek menarik bagi beberapa kalangan pemodal (investor). Di sisi lain, kenaikan dan penurunan harga saham bisa terjadi karena faktor fundamental, psikologis, maupun eksternal.

Terdapat beberapa faktor yang mempengaruhi aktifitas investasi saham di BEI, di antaranya adalah tingkat Inflasi, BI Rate, Nilai Tukar Kurs, Indeks Hang Seng, Indeks Dow Jones dan lainnya. Tingginya tingkat inflasi dapat menurunkan daya beli masyarakat dan juga meningkatnya harga faktor produksi. Hal itu biasanya akan berdampak pada anggapan pesimis mengenai prospek perusahaan yang menghasilkan barang atau jasa yang terkena dampak inflasi sehingga dapat mempengaruhi penawaran harga saham perusahaan tersebut dan pada akhirnya berakibat pada pergerakan indeks harga saham di BEI.

Tingkat suku bunga SBI juga merupakan salah satu variabel yang dapat mempengaruhi harga saham. Secara umum, mekanismenya adalah bahwa suku bunga SBI bisa mempengaruhi suku bunga deposito yang merupakan salah satu alternatif bagi investor untuk mengambil keputusan dalam menanamkan modalnya. Jika suku bunga SBI yang ditetapkan meningkat, investor akan mendapat hasil yang lebih besar atas suku bunga deposito yang ditanamkan sehingga investor akan cenderung untuk mendepositokan modalnya dibandingkan menginvestasikan dalam saham. Hal ini mengakibatkan investasi di pasar modal akan semakin turun dan pada akhirnya berakibat pada melemahnya Harga Saham.

Terdapat alternatif investasi lain yang juga dapat mempengaruhi transaksi saham di bursa efek, yakni investasi pada valuta asing dalam hal ini adalah dollar (USD). Jika saat nilai tukar dollar sedang melemah terhadap rupiah dan dapat diprediksikan akan kembali menguat di masa mendatang, dan juga ketika alternatif investasi lain dirasa kurang menjanjikan, maka investor mungkin cenderung akan menginvestasikan dananya ke dalam bentuk mata uang dollar dengan harapan ketika kurs dollar terhadap rupiah kembali meningkat dia akan menjualnya kembali ke dalam bentuk mata uang rupiah, sehingga dia memperoleh gain dari selisih kurs. Di samping sebagai alternatif investasi, pergerakan mata uang tersebut juga berdampak pada perdagangan ekspor impor barang dan jasa yang berkaitan dengan perusahaan emiten. Kondisi tersebut pada akhirnya akan berdampak pada aktivitas Pasar Modal, dan selanjutnya akan berakibat pada pergerakan Harga Saham di Bursa Efek Indonesia.

Di Indonesia terdapat banyak masalah terkait semen. Pasca terpilihnya Jokowi sebagai Presiden, beliau telah mencanangkan beberapa program pembangunan infrastruktur. Salah satunya terdapat 47 proyek infrastruktur jalan tol yang masuk dalam daftar proyek strategis nasional. Sebanyak 34 proyek jalan tol diantaranya dibangun di Pulau Jawa, sementara di Pulau Sumatera 10 proyek dan masing-masing satu proyek di Kepulauan Riau, Kalimantan Timur dan Sulawesi Utara. Dengan adanya berbagai program pembangunan infrastruktur dari Pemerintah, secara tidak 
langsung akan berdampak pada penjualan semen di Indonesia, karena semen merupakan bahan baku utama yang dibutuhkan. Meningkatnya kinerja dari PT. Semen Indonesia bertolak belakang dengan pergerakan sahamnya yang cenderung fluktuatif. (kompas.com edisi 27 Januari 2016).

Beberapa

penelitian

membahas pengaruh variabel-variabel makro terhadap pergerakan indeks, seperti penelitian yang dilakukan oleh Ellen Rusliati dan Syarah Nurul Fathoni (2011) yang berjudul "Inflasi, Suku Bunga Deposito, Dan Return Pasar Terhadap Return Saham Pada Industri Barang Konsumsi Yang Terdaftar Di BEI 2006-2009”, memperoleh hasil secara parsial inflasi, suku bunga deposito berpengaruh negatif dan signifikan terhadap return saham sedangkan return pasar berpengaruh positif dan signifikan terhadap return saham.

Penelitian yang dilakukan oleh Suskim Riantani dan Maria Tambunan (2013) yang berjudul "Analisis Pengaruh Variabel Makroekonomi dan Indeks Global terhadap Return Saham", memperoleh hasil bahwa Kurs rupiah per dollar AS, suku bunga SBI, Inflasi, Indeks Hang Seng dan Indeks Dow Jones berpengaruh signifikan terhadap return saham.

Berdasarkan penjelasan di atas, maka kerangka pemikiran teoritis dalam penelitian ini dapat digambarkan sebagai berikut:

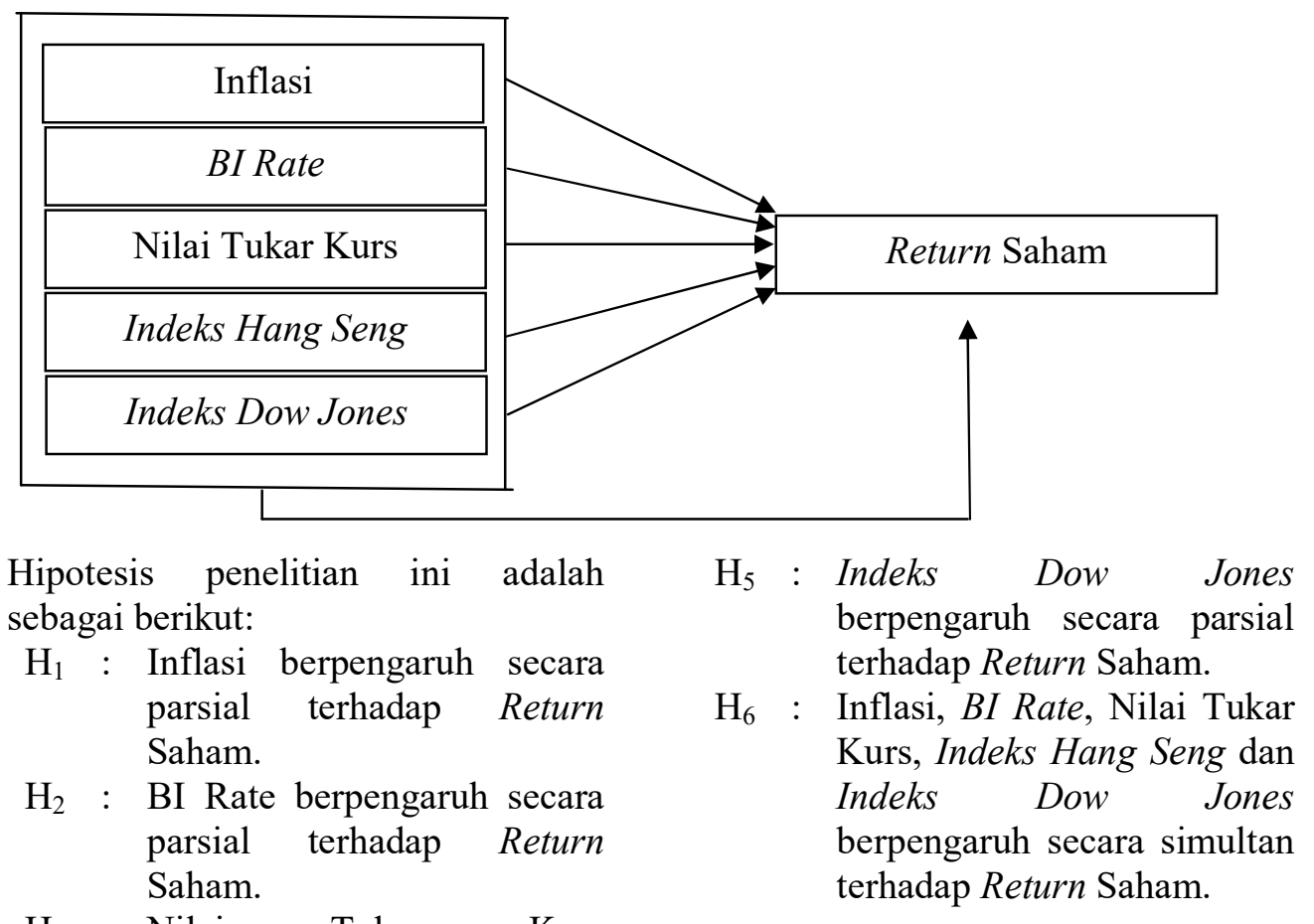

$\mathrm{H}_{3}$ : Nilai Tukar Kurs berpengaruh secara parsial terhadap Return Saham.

$\mathrm{H}_{4}$ : Indeks Hang Seng berpengaruh secara parsial terhadap Return Saham.

\section{METODE PENELITIAN}

Populasi yang digunakan dalam penelitian ini yaitu PT. Semen Indonesia yang terdaftar di BEI tahun 2009-2016. Sampel dalam penelitian 
ini adalah 32. Jenis data yang digunakan dalam penelitian ini adalah data sekunder. Data yang digunakan dari laporan keuangan periode 20092016 yang diperoleh dari website BEI (www.idx.co.id), website perusahaan dan website informasi pembelajaran yang disediakan oleh blogger.

Desain penelitian dalam penelitian ini adalah kuantitatif deskriptif yaitu dengan cara mencari informasi, didefinisikan dengan jelas tujuan yang akan dicapai, merencanakan cara pendekatannya, mengumpulkan data sebagai bahan untuk membuat kesimpulan. Instrument penelitian yang digunakan dalam penelitian ini adalah instrument yang sesuai dengan rumus setiap variabel.

Return saham adalah tingkat keuntungan yang dinikmati oleh pemodal atas investasi yang dilakukannya dengan rumus sebagai berikut:

$$
\text { Return }=\frac{P_{t}-P_{t-1}}{P_{t-1}}
$$

Inflasi adalah perubahan angka inflasi yang dikeluarkan oleh Bank Indonesia pada periode 1
Januari 2009-31 Desember 2016 yang dihitung tiap bulan dalam satuan $\%$.

BI Rate merupakan tingkat bunga yang ditetapkan oleh Bank Indonesia, satuan ukur yang digunakan adalah besarnya tingkat bunga dalam satuan \% pada periode 2009-2016.

Nilai Tukar Kurs adalah nilai nominal USD terhadap mata uang rupiah. Rumusnya sebagai berikut :

Kurs Tengah $=\frac{\text { Kurs Jual }+ \text { Kurs Beli }}{2}$

Indeks Hang Seng adalah sebuah indeks pasar saham berdasarkan kapitalisasi di Bursa Saham Hong Kong. Rumusnya sebagai berikut :

Indeks Hang Seng $=\frac{H S I_{t}-H S I_{t-1}}{H S I_{t-1}}$

Indeks Dow Jones merupakan indeks yang dapat digunakan untuk mengukur performa kinerja perusahaan di Amerika Serikat. Rumusnya sebagai berikut :

Indeks Dow Jones $=\frac{D J I A_{t}-D J I A_{t-1}}{D J I A_{t-1}}$ 
HASIL DAN PEMBAHASAN

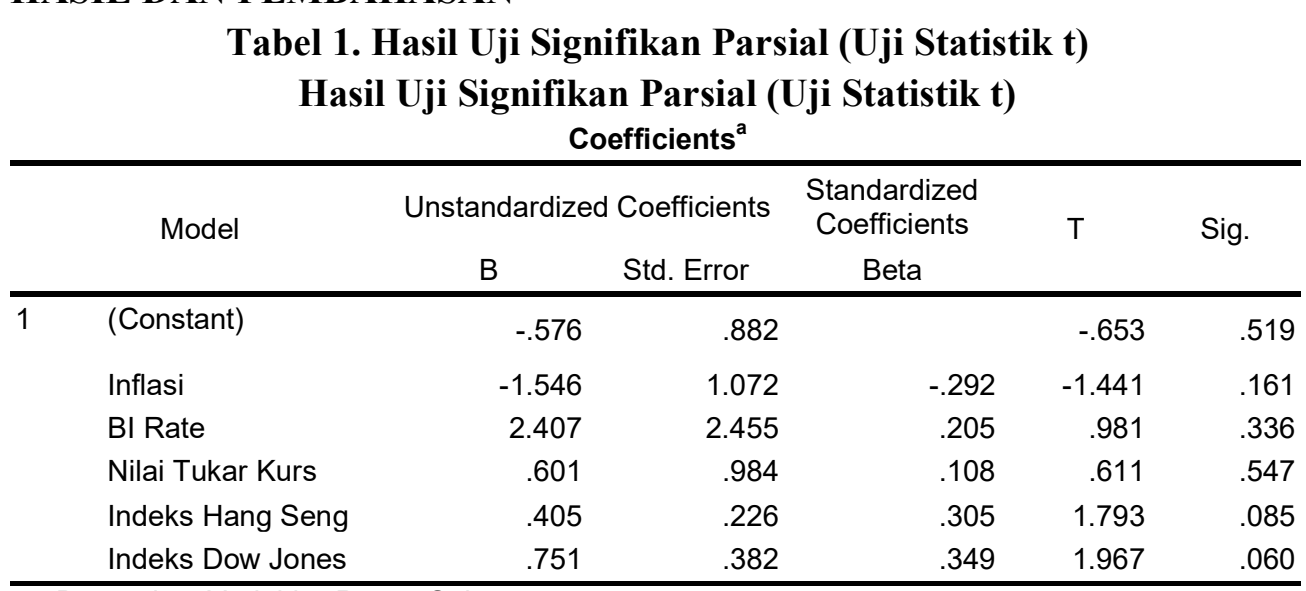

Dependent Variable: Return Saham

Sumber: data diolah

Dapat disimpulkan bahwa hasil uji signifikan parsial (uji statistik t) masing-masing variabel penelitian sebagai berikut:

a. Variabel Inflasi, berdasarkan hasil uji $\mathrm{t}$ diperoleh nilai signifikan sebesar $0,161 \geq 0,05$. Sementara jika dibandingkan nilai $t_{\text {hitung }}$ dengan $t_{\text {tabel }}$ nilai perolehan $t_{\text {hitung }}$ sebesar 0,161 sedangkan $t_{\text {tabel }}$ sebesar 2,05553 ( $\mathrm{df}=\mathrm{n}-\mathrm{k})$. Dari hasil tersebut terlihat $t_{\text {hitung }} \leq \mathrm{t}_{\text {tabel }}$ yaitu $0,161 \leq 2,05553$. Hasil yang menjelaskan bahwa nilai signifikan $\geq 0,05$ dan nilai $t_{\text {hitung }} \leq t_{\text {tabel, }}$ maka $\mathrm{H}_{0}$ diterima dan $\mathrm{H}_{\mathrm{a}}$ ditolak, artinya variabel Inflasi tidak berpengaruh terhadap Return Saham.

b. Variabel BI Rate, berdasarkan hasil uji t diperoleh nilai signifikan sebesar $0,336 \geq 0,05$. Sementara jika dibandingkan nilai $t_{\text {hitung }}$ dengan $t_{\text {tabel }}$ nilai perolehan $t_{\text {hitung }}$ sebesar 0,336 sedangkan $t_{\text {tabel }}$ sebesar 2,05553 ( $d f=n-k)$. Dari hasil tersebut terlihat $\mathrm{t}_{\text {hitung }} \leq \mathrm{t}_{\text {tabel }}$ yaitu $0,336 \leq 2,05553$. Hasil yang menjelaskan bahwa nilai signifikan $\geq 0,05$ dan nilai $t_{\text {hitung }} \leq \mathrm{t}_{\text {tabel, }}$ maka $\mathrm{H}_{0}$ diterima dan $\mathrm{H}_{\mathrm{a}}$ ditolak, artinya variabel BI Rate tidak berpengaruh terhadap Return Saham.

c. Variabel Nilai Tukar Kurs, berdasarkan hasil uji $\mathrm{t}$ diperoleh nilai signifikan sebesar $0,547 \geq$ 0,05 . Sementara jika dibandingkan nilai $t_{\text {hitung }}$ dengan $t_{\text {tabel }}$ nilai perolehan $t_{\text {hitung }}$ sebesar 0,547 sedangkan $t_{\text {tabel }}$ sebesar 2,05553 (df $=\mathrm{n}-\mathrm{k})$. Dari hasil tersebut terlihat $\mathrm{t}_{\text {hitung }} \leq \mathrm{t}_{\text {tabel }}$ yaitu $0,547 \leq 2,05553$. Hasil yang menjelaskan bahwa nilai signifikan $\geq 0,05$ dan nilai $t_{\text {hitung }} \leq \mathrm{t}_{\text {tabel, }}$ maka $\mathrm{H}_{0}$ diterima dan $\mathrm{H}_{\mathrm{a}}$ ditolak, artinya variabel Nilai Tukar Kurs tidak berpengaruh terhadap Return Saham.

d. Variabel Indeks Hang Seng, berdasarkan hasil uji $\mathrm{t}$ diperoleh nilai signifikan sebesar $0,085 \geq$ 0,05 . Sementara jika dibandingkan nilai $t_{\text {hitung }}$ dengan $t_{\text {tabel }}$ nilai perolehan $t_{\text {hitung }}$ sebesar 0,085 sedangkan $t_{\text {tabel }}$ sebesar 2,05553 (df $=\mathrm{n}-\mathrm{k})$. Dari hasil tersebut terlihat $\mathrm{t}_{\text {hitung }} \leq \mathrm{t}_{\text {tabel }}$ yaitu $0,085 \leq 2,05553$. Hasil yang menjelaskan bahwa nilai signifikan $\geq 0,05$ dan nilai $t_{\text {hitung }} \leq \mathrm{t}_{\text {tabel, }}$ maka $\mathrm{H}_{0}$ diterima dan $\mathrm{H}_{\mathrm{a}}$ ditolak, artinya variabel Indeks 
Hang Seng tidak berpengaruh terhadap Return Saham.

e. Variabel Indeks Dow Jones, berdasarkan hasil uji $\mathrm{t}$ diperoleh nilai signifikan sebesar $0,060 \geq$ 0,05 . Sementara jika dibandingkan nilai $t_{\text {hitung }}$ dengan $t_{\text {tabel }}$ nilai perolehan $t_{\text {hitung }}$ sebesar 0,060 sedangkan $\mathrm{t}_{\text {tabel }}$ sebesar 2,05553 (df $=\mathrm{n}-\mathrm{k})$. Dari hasil tersebut terlihat $t_{\text {hitung }} \leq \mathrm{t}_{\text {tabel }}$ yaitu $0,060 \leq 2,05553$. Hasil yang menjelaskan bahwa nilai signifikan $\geq 0,05$ dan nilai $\mathrm{t}_{\text {hitung }} \leq \mathrm{t}_{\text {tabel, }}$ maka $\mathrm{H}_{0}$ diterima dan $\mathrm{H}_{\mathrm{a}}$ ditolak, artinya variabel Indeks Dow Jones tidak berpengaruh terhadap Return Saham.

Tabel 2. Hasil Uji Signifikan Simultan (Uji Statistik F) Hasil Uji Signifikan Simultan (Uji Statistik F) ANOVA $^{\mathrm{D}}$

\begin{tabular}{|c|c|c|c|c|c|c|}
\hline & Model & Sum of Squares & Df & Mean Square & $\mathrm{F}$ & Sig. \\
\hline \multirow[t]{3}{*}{1} & Regression & .105 & 5 & .021 & 3.178 & $.023^{\mathrm{a}}$ \\
\hline & Residual & .172 & 26 & .007 & & \\
\hline & Total & .277 & 31 & & & \\
\hline
\end{tabular}

a. Predictors: (Constant), Indeks Dow Jones, BI Rate, Indeks Hang Seng, Nilai Tukar Kurs, Inflasi

b. Dependent Variable: Return Saham

Sumber: data diolah

Berdasarkan tabel diatas menunjukkan nilai uji $\mathrm{F}$ sebesar 3,178 dengan signifikansi sebesar $0,023 \leq$ 0,05 . Hal ini dapat disimpulkan bahwa vaiabel Inflasi, BI Rate, Nilai Tukar, Indeks Hang Seng dan Indeks Dow Jones secara simultan berpengaruh terhadap Return Saham.

\section{SIMPULAN DAN SARAN}

Berdasarkan hasil penelitian tentang Analisis Pengaruh Inflasi, BI Rate, Nilai Tukar Kurs, Indeks Hang Seng Dan Indeks Dow Jones Terhadap Return Saham (Studi Empiris PT. Semen Indonesia Periode 2009-2016), dapat diambil kesimpulan sebagai berikut:

1. Inflasi tidak berpengaruh terhadap Return Saham.

2. BI Rate tidak berpengaruh terhadap Return Saham.

3. Nilai Tukar Kurs tidak berpengaruh terhadap Return Saham.
4. Indeks Hang Seng tidak berpengaruh terhadap Return Saham.

5. Indeks Dow Jones tidak berpengaruh terhadap Return Saham.

6. Inflasi, BI Rate, Nilai Tukar Kurs, Indeks Hang Seng dan Indeks Dow Jones berpengaruh secara simultan terhadap Return Saham.

Hasil penelitian ini diharapkan dapat memberikan kontribusi dalam pengembangan ilmu ekonomi. Penelitian ini terdapat beberapa keterbatasan adalah sebagai berikut:

1. Bagi Peneliti Selanjutnya, diharapkan dapat menambah perusahaan yang di analisis. Pada penelitian ini, jumlah sampel yang digunakan sedikit. Penelitian yang akan datang disarankan menambah sampel yang akan diuji, tidak hanya PT Semen Indonesia saja.

2. Menambahkan variabel lain, agar dapat menghasilkan data yang 
lebih baik seperti PDB (Produk Domestik Bruto).

\section{DAFTAR PUSTAKA}

Amin, Muhammad Zuhdi, \& Herawati, Tuban Drijah. 2012. Pengaruh Tingkat Inflasi, Suku Bunga SBI, Nilai Kurs Dollar (USD/IDR), dan Indeks Dow Jones (DJIA) terhadap pergerakan Indeks Harga Saham Gabungan di Bursa Efek Indonesia (BEI) (Periode 20082011). Jurnal Skripsi.

Dwita, Vidyarini, \& Rahmidani, Rose. 2012. Pengaruh Inflasi,
Suku Bunga dan Nilai Tukar terhadap Return Saham Sektor Restoran, Hotel dan Pariwisata. Jurnal Kajian Manajemen Bisnis. Vol.1. No.1

https://www.google.com/search?q=pr oyek + jokowi $+47+$ tol\&ie $=$ utf-

$\underline{8 \text { \&oe }=\text { utf- } 8}$

www.bi.go.id/id/moneter/birate/data/Default.aspx

Sodikin, Akhmad. 2007. Variabel Makro Ekonomi yang mempengaruhi Return Saham di BEJ. Jurnal Manajemen Vol.6. No.2. 